\title{
Biological properties of a novel coladerm-beta glucan membrane. In vitro assessment using human fibroblasts
}

\author{
Sona Jantova ${ }^{a}$, Dusan Bakos ${ }^{b}$, Lucia Birosovaa ${ }^{a}$, Patrik Matejov ${ }^{a}$
}

\begin{abstract}
Aim. The purpose of this study was to prepare a coladerm-beta glucan membrane (CBGM) and to evaluate its biocompatibility, cytotoxicity, antimicrobial activity, genotoxicity and mutagenicity.

Methods. The biocompatibility of the membrane was studied on the base of cell adhesion and colonization of human fibroblasts on the biomaterial surface by light microscopy. The MTT test and LDH level determination in the culture medium removed from the control and cells treated on the membrane, were used for viability and cytotoxic evaluations. Flow cytometry and gel electrophoresis were used for analysis of cell cycle and death. The antimicrobial activity of CBGM was tested using the qualitative dilution method. Ames bacteria gene mutation test and Comet assay were used for mutagenic and genotoxic studies.

Results. MTT and LDH tests confirmed that CBGM is a non-toxic biomaterial. Flow cytometry and gel electrophoresis demonstrated that the membrane did not affect the cell cycle and did not induce either necrotic or apoptotic cell death. CBGM exhibited antibacterial activity against $\mathrm{G}^{-}$bacteria $E$. sakazakii, S. marcescens, E. coli and agains $\mathrm{G}^{+}$sporogenic bacteria $B$. cereus. No antifungal activity was detected. The membrane did not induce mutagenicity in the bacterial reverse mutation test in Salmonella Typhimurium strains. Similarly, the comet assay showed that the tested fibroblast cells growing with/without the membrane did not show any statistically significant DNA damage.

Conclusions. The CBGM has good biocompatibility, no cytotoxicity/genotoxicity/mutagenicity and it can be included as a potential scaffold for tissue engineering.
\end{abstract}

Key words: coladerm-beta glucan membrane, human fibroblasts, biocompatibility, cytotoxicity, genotoxicity, antimicrobial activity

Received: July 4, 2012; Accepted with revision: December 19, 2012; Available online: February 14, 2013 http://dx.doi.org/10.5507/bp.2012.115

anstitute of Biochemistry, Nutrition and Health Protection, Faculty of Chemical and Food Technology, Slovak University of Technology, Radlinskeho 9, 81237 Bratislava, Slovak Republic

bInstitute of Polymer Materials, Faculty of Chemical and Food Technology, Slovak University of Technology, Radlinskeho 9, 81237 Bratislava, Slovak Republic

Corresponding author: Lucia Birosova, e-mail: lucia.birosova@stuba.sk

\section{INTRODUCTION}

The scale of synthetically prepared biomaterials used in clinical practice as tissue substitutes is broad. It is generally preferred to improve their surface properties for better cell adhesion and colonization. In tissue engineering, 3D scaffolds are developed to support cells, promoting their differentiation and proliferation towards the formation of new regenerative tissue. Different materials have been proposed for use in scaffolds processing, particularly biodegradable polymers.

Collagen as the most abundant protein in the body is also the most investigated for biomedical applications ${ }^{1}$. This is due to its excellent biocompatibility, biodegradability and low antigenicity. Collagen in biomaterials, provides mechanical stability and structural guidance for cells, as well as facilitates the cell attachment. Collagenbased materials have found various applications in the biomedical fields particularly in skin tissue engineering. The complex membranes based on collagen, prepared with natural and biodegradable synthetic polymers, have many applications not only as skin replacements but also as a support for toxicity testing. However, tissue engineer- ing is currently an exciting area for the applications of such membranes. Chemically modified collagen-based scaffolds with programmable biodegradability are among the progressive biomaterials being used as a substitute for buccal mucosa, skin, cartilage, etc. $\left(\right.$ ref. $\left.^{2}\right)$.

Beta-glucans are polysaccharides consisting of a glucose residue jointed by beta linkage ${ }^{3}$ and manifest a broad spectrum of biological activities: antimicrobial, anti-infective, anti-inflammatory, anti-arthritis, antihypertension, chemoprotective, antitumor, and immunostimulatory activity $^{46}$. They are taken as herbal medicines, to prevent and treat cancer, lower cholesterol, for human immunodeficiency virus (HIV), and diabetes, and to increase the immune system function. $\beta$-glucans are also used as medicine for colds (common cold), flu (influenza), H1N1 (swine) flu, allergies, hepatitis, Lyme disease, asthma, ear infections, aging, ulcerative colitis and Crohn's disease, fibromyalgia, rheumatoid arthritis, and multiple sclerosis ${ }^{7}$. Some fungal glucans, e.g. lentinon and schizophyllan, are already used clinically for cancer therapy in Japan ${ }^{7.9}$. Mushroom polysaccharides prevent oncogenesis, show direct antitumor activity against various allogeneic and syngeneic tumors, and prevent tumor metastasis ${ }^{10,11}$. 
Moreover, some authors have also reported potential effects of beta-glucans on photodynamic therapy. Natural products containing beta-glucans have been used for thousands of years for the benefits of human health, but beta-glucans were only identified as active components recently. Studies also showed that beta-glucans have great potential for the treatment of diabetes. Beta-glucan such as zymosan has been shown to be beneficial in wound healing. It may increase collagen synthesis ${ }^{12}$.

Beta-glucans are found in the cell wall of yeast, fungi and pathogenic bacteria and they are also produced by a variety of plants.

The biological activities of beta glucan isolated from Pleurotus ostreatus is $B-(1,3 / 1,6)-\mathrm{D}$ glucan (pleuran) have been reported ${ }^{6,13-16}$. The effects of Pleurotus ostreatus administration on a cancer outbreak and activities of macrophages and lymphocytes in mice treated with carcinogen N-butyl-N-butanolnitrosoamine were described by Kurashige et al. ${ }^{17}$. Nosál'ová et al. ${ }^{13}$ demonstrated a possible role of beta-glucan isolated from Pleurotus ostreatus in a treatment of ulcerative colitis. Bobek and Galbavý ${ }^{18}$ reported the effect of pleuran on the antioxidant status of the organism and on dimethylhydrazine-induced precancerous lesions in rat colon. The results of Majtán et al. ${ }^{14}$ indicated that pleuran is a potent keratinocyte stimula-
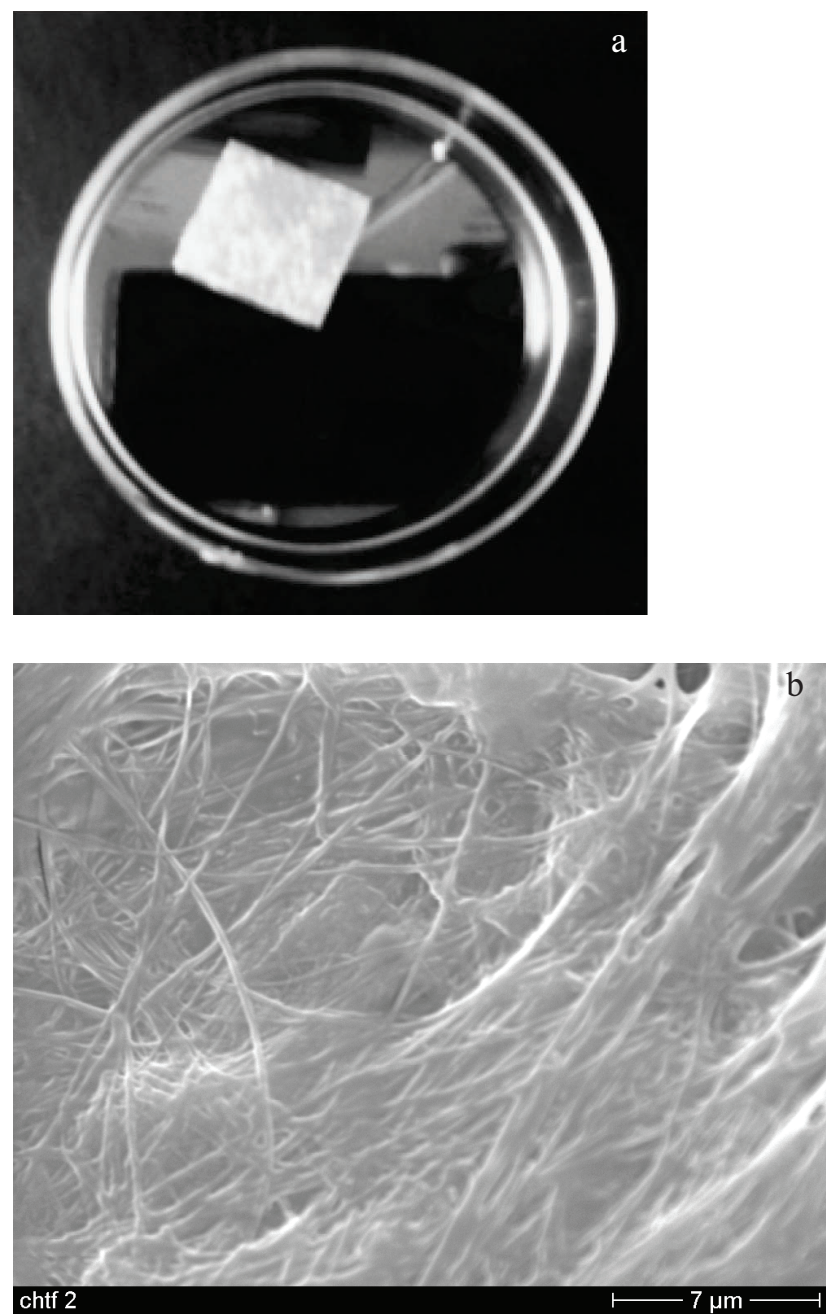

tor of prometalloproteinase 9 release, which implies its application in dermatological therapies. Pleuran from Pleurotus ostreatus may participate in physiological processes related to the metabolism of fats in the human body ${ }^{15}$. Rovenský et al. ${ }^{16}$ evaluated the effect of betaglucan-PO (beta glucan isolated from Pleurotus ostreatu) on the prophylactic treatment of adjuvant arthritis with methotrexate in rats. The authors demonstrated that betaglucan-PO reduced arthritis development in rats and had additional beneficial effects to methotrexate treatment. Bergendiova et al. $^{6}$ found that water insoluble pleuran significantly reduced the incidence of upper respiratory tract infections (URTI) symptoms and increased the number of NK cells. In addition, pleuran significantly improved the phagocytosis process. The authors suggested that pleuran, supplementation may have the capacity to attenuate immune changes and decrease URTI symptoms in intensively training athletes ${ }^{6}$.

In previous work ${ }^{19}$ a membrane based on atelocollagen complex with hyaluronan and chemically modified with starch dialdehyde derivatives (coladerm) was prepared and tested on cytotoxicity. Testing with human embryonic fibroblasts B-HNF-2 showed the non-toxicity of the coladerm membrane (collagen-hyaluronan membrane) $\left(\right.$ ref. $\left.^{20}\right)$. Moreover, the membrane had suitable structural and biological properties for such clinical application as substituting buccal mucosa after surgical ablation of malignant tissues from the oral cavity ${ }^{2,21-23}$.

The aim of this study was to prepare a coladerm-beta glucan membrane (collagen-hyaluronan-beta glucan membrane, CBGM) and to evaluate its biocompatibility, cytotoxicity, antimicrobial activity, genotoxicity and mutagenicity.

\section{MATERIALS AND METHODS}

\section{Preparation of coladerm-beta glucan membrane}

The samples of the CBGM (Fig. 1) were prepared using atelocollagen Hypro-Sorb ${ }^{\circledR}$ (Hypro, Zlin, Czech Republic). $1.5 \mathrm{~g}$ of atelocollagen was desintegrated in $50 \mathrm{~mL}$ of deionized water and subsequently $10 \mathrm{~mL} 0.05 \mathrm{M}$

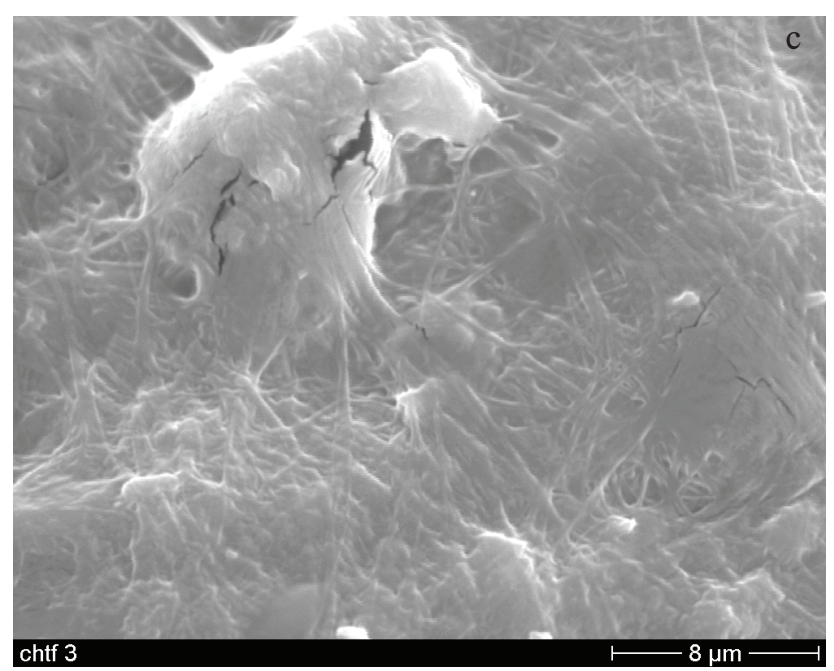

Fig. 1. Coladerm-beta glucan membrane structure: light microscopy - macrostructure (a), Scanning electron microscop - collagen fiber (b), collagen fiber ambient $\beta$-glucan granule (c). A beta glucan pacticle is indicated by the arrow ${ }^{17}$. 
acetic acid was added to the mixture. Sodium hyaluronan (MW 180 000, CNP, Ústí nad Orlicí, Czech Republic) in an amount of $0.12 \mathrm{~g}$ was dissolved during $2-3 \mathrm{~h}$ in 10 $\mathrm{mL}$ of deionized water added to collagen suspension and mixed together. After that, $2.3 \mathrm{~mL}$ of $1.3 \%$ (w/w) solution of starch dialdehyde was added with subsequent mixing. Finally, $0.5 \mathrm{~g}$ of micronized beta glucan with particles size 5-10 $\mu$ m (NATURES, Slovak republic) was added to the mixture. The homogeneous mixture was dosed with the syringe $(20-25 \mathrm{~mL})$ to the Teflon forms and dried in an oven at $37^{\circ} \mathrm{C}$ during 2-3 days. After drying, the membrane was cut into squares $1 \mathrm{~cm}^{2}$ in size and sterilized by $\gamma$-irradiation using the dose $25 \mathrm{kGy}\left(\right.$ ref. $\left.^{24}\right)$.

\section{Starch dialdehyde preparation}

After mixing $16.2 \mathrm{~g}$ of maize starch with $100 \mathrm{~mL}$ of deionized water, the solution of $23.5 \mathrm{~g}$ sodium periodate in $300 \mathrm{~mL}$ of deionized water was dropping over one hour into this white suspension. After the suspension was mixed at a temperature $25{ }^{\circ} \mathrm{C}$ during next $18 \mathrm{~h}$ and filtered by throughout washing of a filtrate six times with $50 \mathrm{~mL}$ of deionized water. Finally, the modified starch was rinsed by $100 \mathrm{~mL}$ of acetone and dried at $40{ }^{\circ} \mathrm{C}$ for $24 \mathrm{~h}$. Starch aldehyde solution was prepared by dissolving the product in $\mathrm{NaHCO}_{3}$ saturated solution to reach the concentration of $1.3 \%(\mathrm{w} / \mathrm{w})$.

\section{Other chemicals}

Dulbecco's Modified Eagles Medium (DMEM), fetal bovine serum (FBS), trypsin and antibiotics were purchased from Biocom Company (Bratislava, Slovak republic). Trypan blue and all other chemicals used were purchased from Sigma Chemicals (St. Louis, MO, USA).

\section{In vitro cell culture tests}

Nonmalignant diploid human foreskin fibroblasts VH10 were obtained from D. Slameňová (Cancer Research Institute Bratislava, Slovak Academy of Sciences, Slovak republic), human neonatal diploid cell line B-HNF-1 was obtained from the collection of the Institute of medical biology, genetics and clinical genetics (Comenius University in Bratislava, Slovakia) and were grown (starting inoculum $1 \times 10^{5} \mathrm{VH} 10$ cells $/ \mathrm{mL}$ and 5 $\mathrm{x} 10^{4} \mathrm{~B}-\mathrm{HNF}-1$ cells/mL) in DMEM supplemented with $10 \%(\mathrm{v} / \mathrm{v})$ FBS, penicillin $\mathrm{G}(100 \mathrm{mg} / \mathrm{L})$, streptomycin $(100 \mathrm{mg} / \mathrm{L})$ and kanamycine $(100 \mathrm{mg} / \mathrm{L})$ at $37^{\circ} \mathrm{C}$ in humidified $6 \% \mathrm{CO}_{2}$ and $94 \%$ air atmosphere. Before a confluent monolayer was formed, the cells were harvested from the culture surface by incubation with a trypsin solution $(0.25 \%)$. When a suitable cell concentration had been reached, the suspension was used for the experiments. The cells were at the time in the exponential phase of growth. All experiments were performed in Petri dishes ( $600 \mathrm{~mm}$ ). Cell viability was determined by the Trypan blue exclusion test.

\section{Light microscopy}

After trypsinization and dispersing in culture medium, a cell suspension of density of $2 \times 10^{5}$ (VH10) and $1 \mathrm{x}$
$10^{5}$ (B-HNF-1) cells/mL was prepared. Sterile coladerm-glucan membranes were placed on the bottom of the Petri dishes and treated with $0.5 \mathrm{~mL}$ of the cell suspension. After $1 \mathrm{~h}$, the culture medium $(4.5 \mathrm{~mL})$ was added and cells were cultured for 2, 3, 6 and 7 days at $37{ }^{\circ} \mathrm{C}$ in a humidified atmosphere containing 5\% (v/v) $\mathrm{CO}_{2}$. After treating, the membranes were examined under a light microscope (Meopta, Slovak republic) and photographed. The cells cultured without CBGM were used as a control.

\section{MTT test}

Cell viability was evaluated using 3-(4,5-dimethyl(thiazol-2-yl)-2,5-diphenyltetrazolium bromide) (MTT), the reagent which measures the metabolic activity of cells ${ }^{25}$. The stock solution of MTT $(5 \mathrm{mg} / \mathrm{mL})$ was prepared in phosphate-buffered saline (PBS) and stored in the dark at $4{ }^{\circ} \mathrm{C}$. A $100 \mu \mathrm{L}$ aliquot of a dilution prepared in unsupplemented culture medium ( $1 \mathrm{mg} / \mathrm{mL}$ final) was filtered $(0.22 \mu \mathrm{m})$ and added to the cells growing with/without CBGM. After $3 \mathrm{~h}$ of incubation the supernatant was removed. Formazan crystals in viable cells were dissolved in ethanol $(96 \% \mathrm{v} / \mathrm{v})$ and absorbance was measured by the MULTISKAN ${ }^{\circledR}$ FC microplate photometer (Thermo Scientific, USA) at $540 \mathrm{~nm}$.

\section{Lactate dehydrogenase (LDH) quantification}

LDH release is an important and frequently applied test for cellular membrane permeabilization and severe irreversible cell damage. The amount of released LDH was measured according to Bergmeier ${ }^{26}$.

After incubation periods, the medium was aspirated from each sample together with the control and stored on ice. Then, the standard solutions for samples with released LDH was prepared (containing $100 \mathrm{mM}$ Tris- $\mathrm{HCl}$ buffer, pH 7.1, $15 \mathrm{mM}$ of NADH and 1.0 M of pyruvate sodium salt) as well as the standard solution of the total LDH (the same composition but plus $10 \%$. solution of Triton-X-100). The standard solutions were incubated at $31{ }^{\circ} \mathrm{C}$ for 5-10 min before the measurement. Oxidation of NADH was measured by the photometer MULTISKAN ${ }^{\circledR}$ FC (Thermo Scientific, USA) at $340 \mathrm{~nm}$. Absorbance decreased linearly with time over $60 \mathrm{~s}$ of measurement ${ }^{27}$.

\section{Cell cycle analysis}

Flow cytometry was used for the cell cycle analysis of the control and the membranes treated VH10 and B-HNF-1 cells. Cells at the amount of $0.5 \times 10^{6}$ growing $96 \mathrm{~h}$ in/without presence of the CBGM were harvested and washed twice in PBS. Cells were exposed to $0.1 \%$ Triton X-100 in PBS supplemented with RNA-ase (50 $\mu \mathrm{g} / \mathrm{mL}$ ) during $25 \mathrm{~min}$ at $37^{\circ} \mathrm{C}$. Afterwards, DNA was stained with propidium iodide $(50 \mu \mathrm{g} / \mathrm{mL})$ for $15 \mathrm{~min}$ at 4 ${ }^{\circ} \mathrm{C}$. The samples were analyzed by the Coulter Epics XL (Beckman Coulter Company, USA) flow cytometer using DNA Cell Cycle Analysis Software distributed by Phoenix Flow Systems - MultiCycle AV for Windows. Minimally 10000 cells per sample were analyzed at a flow rate of 200 cells/s. Excitation was measured at $488 \mathrm{~nm}$ using argon laser. 


\section{Agarose gel electrophoresis}

VH10 and B-HNF-1 cells growing $96 \mathrm{~h}$ with/without the CBGM were harvested, washed in PBS and lysed in $100 \mu \mathrm{l}$ of the solution containing $10 \mathrm{mM}$ of Tris, $10 \mathrm{mM}$ of EDTA and $0.5 \%$ (w/w) of Triton X-100 supplemented with proteinase $\mathrm{K}(1 \mathrm{mg} / \mathrm{mL})$. Samples were then incubated at $37{ }^{\circ} \mathrm{C}$ for $1 \mathrm{~h}$ and heated at $70{ }^{\circ} \mathrm{C}$ for $10 \mathrm{~min}$ A repeated incubation at $37^{\circ} \mathrm{C}$ during $1 \mathrm{~h}$ followed after adding RNA-ase $(200 \mu \mathrm{g} / \mathrm{mL})$. The samples were subjected to electrophoresis at $40 \mathrm{~V}$ for $3 \mathrm{~h}$ in $2 \%(\mathrm{w} / \mathrm{w})$ agarose gel complemented with EtBr $(1 \mu \mathrm{g} / \mathrm{mL})$. Separated DNA fragments were visualized using the UV transilluminator (254 nm, Ultra-Lum Electronic UV Transilluminator, USA).

\section{Comet assay}

The procedure of Singh et al. ${ }^{28}$ was used with minor changes suggested by Slameňová et al. ${ }^{29}$ and Gábelová et al. ${ }^{30}$. A base layer of normal melting point (NMP) agarose ( $100 \mu$ of $0.75 \%$ wt.) in PBS buffer $\left(\mathrm{Ca}^{2+}\right.$ - and $\mathrm{Mg}^{2+}$ - free $)$ was placed on microscope slides. Human fibroblast VH10 and B-HNF-1 cells were grown with/without the CBGM for $24 \mathrm{~h}$. Both membrane-treated and control cells were suspended in low melting-point (LMP) agarose $(0.75 \%$ $\mathrm{w} / \mathrm{w})$. The aliquot of $85 \mu \mathrm{L}$ of LMP agarose, containing 2 x $10^{4}$ cells, was spread on the base layer. Triplicate slides were prepared per sample. After solidifying of agarose, the slides were placed into the lysis mixture (composed of 2.5 $\mathrm{M} \mathrm{NaCl}, 100 \mathrm{mM} \mathrm{Na}$ EDTA, 10 mM Tris-HCl, pH 10.0 and freshly added $1 \%$ Triton X-100) at $4{ }^{\circ} \mathrm{C}$. The slides were then transferred to the electrophoresis box with alkaline solution ( $300 \mathrm{mM} \mathrm{NaOH}, 1 \mathrm{mM} \mathrm{Na}$ EDTA, $\mathrm{pH}$ > 13) and kept in this solution for $40 \mathrm{~min}$ at $4{ }^{\circ} \mathrm{C}$ to unwind DNA strands. The voltage $25 \mathrm{~V}(300 \mathrm{~mA})$ was applied for $30 \mathrm{~min}$ The slides were removed, neutralized by $2 \times 10$ min washing in Tris- $\mathrm{HCl}(0.4 \mathrm{M}, \mathrm{pH}=7.5)$ and stained with $20 \mu \mathrm{L}$ ethidium bromide $(10 \mu \mathrm{g} / \mathrm{mL}$ of $\mathrm{EtBr})$. Stained nucleoids were evaluated with the Zeiss Jenalumar fluorescence microscope (magnification $200 \times$ ). For each sample 100 comets were scored by the computerized image analysis (Komet 5.5 Europe, Kineting Imaging, Liverpool, UK) to determine DNA in the tail, linearly related to the frequency of DNA strand breaks ${ }^{30}$.

\section{In vitro microbial tests}

Microbial strains Staphylococcus aureus CCM 3953, Staphylococcus epidermidis CCM 4418, Streptococcus pyogenes CCM 4425, Bacillus cereus CCM 2010, Escherichia coli CCM 3988, Enterobacter sakazakii CCM 3461, Serratia marcescens CCM 303, Proteus sp. CCM 1799, Saccharomyces cerevisiae CCM 8191, Candida albicans CCM 8186 (obtained from Czech Collection of Microorganisms, Masaryk University, Brno, Czech Republic), Alternaria alternata, Aspergillus niger, Penicilium purpurogenum, Rhizopus oryzae (Collection of Microorganisms of Department of Biochemistry and Microbiology, Faculty of Chemical and Food Technology STU, Bratislava, Slovak republic), Microsporum gypseum, Trichophyton interdigitale (Laboratory of Medical Mycology, Postgraduate Medical Institute, Bratislava,
Slovak republic) were used for antibacterial respectively antifungal assay. Bacterial strains Salmonella Typhimurium TA 98 (CCM 3811) and TA100 (CCM 3812) (obtained from Czech Collection of Microorganisms, Masaryk University, Brno, Czech Republic) were used in bacterial mutagenicity tests. Subcultures were prepared separately in Petri dishes containing appropriate agar medium and incubated at $30{ }^{\circ} \mathrm{C}$ for $48 \mathrm{~h}$ (bacteria, yeasts) and at 25 ${ }^{\circ} \mathrm{C}$ for $96 \mathrm{~h}$ (filamentous fungi).

\section{Antimicrobial assay}

The antimicrobial activity of CBGM was tested using the qualitative method according to Bodajla et al. ${ }^{31}$ with a small modification. The membrane was put on agar plates in Petri dishes inoculated with bacteria or with suspensions of spores of filamentous fungi. The plates with bacteria were incubated for $20 \mathrm{~h}$ at $37{ }^{\circ} \mathrm{C}$ and examined for zones of inhibition. Filamentous fungi and yeast were incubated at $25^{\circ} \mathrm{C}$ and the plates with Rhizopus oryzae, Saccharomyces cerevisiae and Candida albicans were examined after $20 \mathrm{~h}$, with Aspergillus niger and Penicilium purpurogenum after $48 \mathrm{~h}$ and with Alternaria alternata, Microsporum gypseum and Trichophyton interdigitale after $64 \mathrm{~h}$.

\section{Bacterial mutagenicity test}

Bacterial strains Salmonella Typhimurium TA100 and TA98 which are sensitive to a broad spectrum of chemical compounds were cultivated on nutrient agar. The overnight culture was prepared in nutrient broth 16 $\mathrm{h}$ before the experiment. The plate-incorporation method according to Maron and Ames ${ }^{32}$ without metabolic activation was used. To $2 \mathrm{~mL}$ of melted top agar with $50 \mu \mathrm{M}$ of L-histidine-biotin, $0.1 \mathrm{~mL}$ of a cell suspension (overnight cultivation at $37{ }^{\circ} \mathrm{C}$, approximate cell density $2-5 \times 10^{8}$ cells $/ \mathrm{mL}$ ) and (homogenized) membrane were added. The mixture was poured onto a minimal glucose agar plate and incubated for $48 \mathrm{~h}$ at $37{ }^{\circ} \mathrm{C}$ and the number of histidine-independent revertants was counted. The data points represent at least three separate experiments. A positive response was defined as a reproducible, twofold increase in revertants with dose-response relationship.

\section{Statistical analysis}

The assays were performed in triplicate and the data were expressed as means \pm standard deviations (SD). The one-way ANOVA combined with a Student-NewmanKeuls (SNK) post hoc test was used to determine the level of significance: $P<0.05$ (for cell cycle analysis and comet assay) and $* * * P<0.001$ (for Ames test).

\section{RESULTS}

\section{Fibroblast adhesion, proliferation and cytotoxicity}

The ability of VH10 cells to adhere on the surface of the newly prepared CBGM (Fig. 1) after 1, 2, 3, 6 and 7 days is demonstrated in Fig. 2. After 1, 2 and 3 days of cultivation, cells did not adhere sufficiently on the membrane 

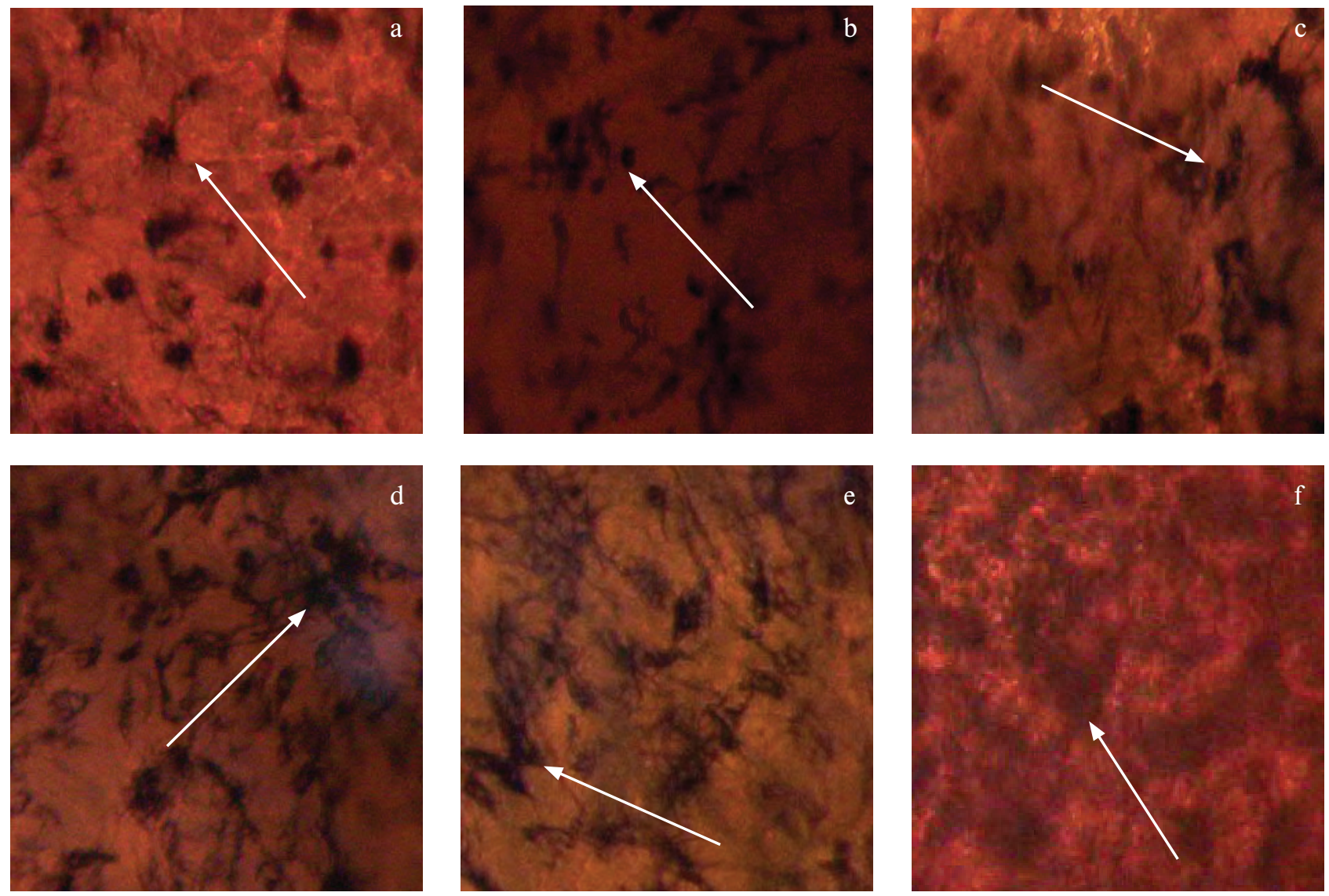

Fig. 2. The ability of VH10 cells to adhere and divide on the coladerm-beta glucan membrane surface after 1 (a), 2 (b), 3 (c), 6 (d) and 7 (e) days of cultivation. The membrane without VH10 cells was used as a control (f). Adhered cells are indicated by the arrows. Magnification: $160 \times$.

surface (Fig. 2 a, b, c). On the other hand, an increased number of adhered cells were found after 6 and 7 days of the cultivation (Fig. 2 d, e). The cells grew adhered on the membrane surface and porous and colonized the heterogeneous surface in all directions.

Cell viability and cytotoxicity of the CBGM were monitored by the MTT test and by the LDH level determination in the culture medium removed from the control and cells treated on the membrane. The cells growing without the CBGM were used as a control. The viability of VH10 cells culturing with/without the CBGM was measured over 4 days. No significant difference in cell viability or growth was found during the whole culturing period. VH10 cells at the membrane grew at almost the same extent as the control cells growing without the CBGM.

Fig. 3 demonstrates the effect of the CBGM on LDH release in VH10 and B-HNF-1 cells after 4 days of the cultivation. The percentage of $\mathrm{LDH}$ release was determined as the ratio of the released amount of $\mathrm{LDH}$ to the total LDH amount. As seen in Fig. 4, no increase in $\mathrm{LDH}$ released was found in comparison to the control in either cell line used. These results correlate with those of the experiments of viability/cytotoxicity assessment by the MTT test.

\section{Analysis of cell cycle and apoptotic death of the VH10 and B-HNF-1 cells}

In order to investigate the effect of CBGM on cell cycle profile of cell lines VH10 and B-HNF-1, the cells were exposed to biomaterial and after 4 days the cell cycle profile was analyzed using flow cytometry. As shown in Table 1 less change in cell cycle was found and a decrease in cell number in $\mathrm{S}$ and $\mathrm{G} 2 / \mathrm{M}$ phases (34.4\% and 39.7\% for VH10 cells; $20 \%$ and $12.4 \%$ for B-HNF-1 cells) was observed.

Further the ability of the CBGM to induce apoptosis we studied. Induction of apoptotic death of control and membrane-treated VH10 and B-HNF-1 cells was examined after 4 days of incubation using agarose gel electrophoresis (Fig. 4). Apoptotic cells form apoptotic DNA fragment in agarose gel. As seen from figure, no apoptotic DNA fragmentation was detected.

\section{Antibacterial and antifungal assay}

Antimicrobial activity of CBGM monitored on the bacteria, yeast and filamentous fungi models using the diffusion method is shown in Table 2. Best antibacterial activity was determined against $\mathrm{G}^{-}$bacteria and against $\mathrm{G}^{+}$sporogenic bacteria $B$. cereus. No antifungal activity was detected. 
Table 1. Percentage values of cells in subG0, G0/G1, S and G2/M phases determined by flow-cytometric analysis of control (cells without membrane) and treated VH10 and B-HNF-1 cells (cells with membrane). Results are expressed as mean \pm SD (the differences are statistically significant).

\begin{tabular}{|c|c|c|c|c|}
\hline Cell cycle phases & Sub-G ${ }_{0}$ & $\mathrm{G}_{0} / \mathrm{G}_{1}$ & $\mathrm{~S}$ & $\mathrm{G}_{2} / \mathrm{M}$ \\
\hline \multicolumn{5}{|c|}{ VH10 cells } \\
\hline$\%$ control cells in phases & $1.94 \pm 0.08$ & $84.51 \pm 5.12$ & $7.52 \pm 0.52$ & $7.98 \pm 0.34$ \\
\hline$\%$ treated cells in phases & $0.56 \pm 0.02$ & $90.28 \pm 4.01$ & $4.93 \pm 0.16$ & $4.79 \pm 0.21$ \\
\hline \multicolumn{5}{|c|}{ B-HNF-1 cells } \\
\hline$\%$ control cells in phases & $1.52 \pm 0.09$ & $88.12 \pm 5.03$ & $6.81 \pm 0.26$ & $5.08 \pm 0.38$ \\
\hline$\%$ treated cells in phases & $0.62 \pm 0.03$ & $87.39 \pm 5.75$ & $5.45 \pm 0.50$ & $4.45 \pm .19$ \\
\hline
\end{tabular}

$\mathrm{N}=3, P<0.05$ was considered statistically significant.

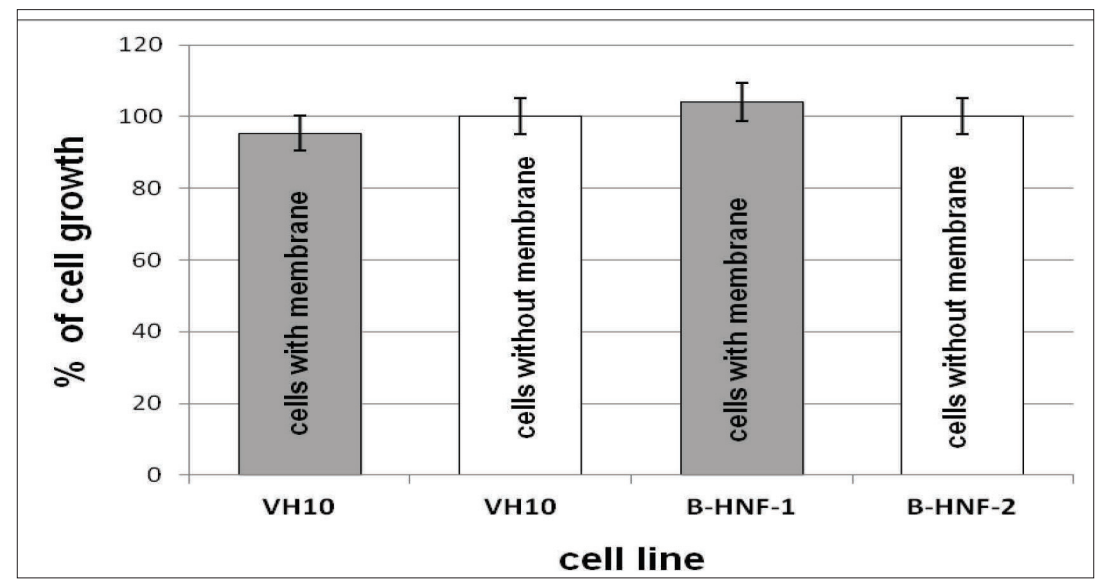

Fig. 3. Percentage of LDH release from VH10 and B-HNF-1 cells in/without presence of coladerm-beta glucan membrane.

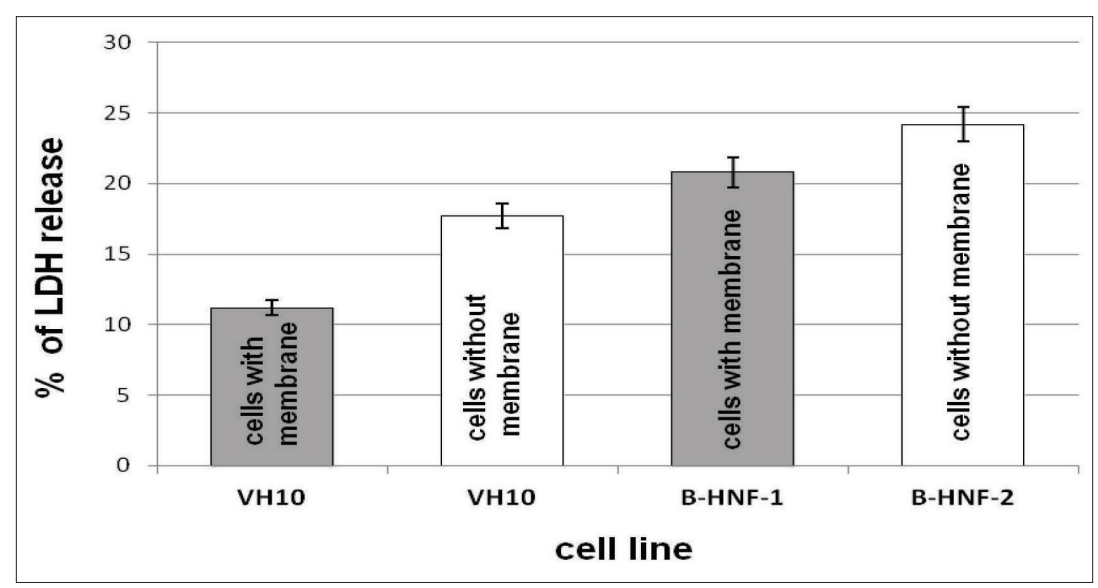

Fig. 4. Detection of apoptotic DNA fragmentation in human fibroblast cells treated with coladerm-beta glucan membrane for 4 days. a - VH10 cells without membrane (negative control); b - VH10 cells with membrane (b); c - positive control (the cells treated with $6 \mu \mathrm{M}$ cisplatin for $24 \mathrm{~h}$ ); $\mathrm{d}$ - B-HNF-1 cells without membrane (negative control); e - B-HNF-1 cells with membrane.

\section{Genotoxic studies}

The results of monitoring the potential of the CBGM to induce mutations in the bacterial strains $S$. Typhimurium TA98 and TA100 are given in Table 3. As seen, the tested membrane did not induce growth of revertants. No mutagenic activity was observed.
The effects of the CBGM on DNA damage in VH10 and B-HNF-1 cells monitored by Comet assay after $24 \mathrm{~h}$ of influence are illustrated in Fig. 5 and 6. From the figures, tested cells growing with/without the CBGM showed no statistically significant DNA damage. No comet tails were found. 
Table 2. Antimicrobial effect of coladerm-beta glucan membrane.

\begin{tabular}{|c|c|}
\hline Tested bacteria and fungi & $\begin{array}{c}\text { Inhibition zone } \\
\text { of membrane }(\mathrm{mm})\end{array}$ \\
\hline Proteus sp. CCM 1799 & $\mathrm{NI}$ \\
\hline E. sakazakii CCM 3461 & 15 \\
\hline S. marcescens CCM 303 & 12 \\
\hline E. coli CCM 3988 & 13 \\
\hline S. epidermidis CCM 4418 & NI \\
\hline S. pyogenes CCM 4425 & $\mathrm{NI}$ \\
\hline B. cereus CCM 2010 & 15 \\
\hline S. aureus CCM 3953 & $\mathrm{NI}$ \\
\hline A. niger & NI \\
\hline P. purpurogenum & NI \\
\hline R. oryzae & NI \\
\hline A. alternata & NI \\
\hline M. gypseum & $\mathrm{NI}$ \\
\hline T. interdigitale & NI \\
\hline S. cerevisiae CCM 8191 & NI \\
\hline C. albicans CCM 8186 & $\mathrm{NI}$ \\
\hline
\end{tabular}

NI - no inhibition

\begin{tabular}{|l|l|l|l|l|}
\hline $\mathbf{a}$ & $\mathbf{b}$ & $\mathbf{c}$ & $\mathbf{d}$ & $\mathbf{e}$ \\
\hline & & & & \\
\hline
\end{tabular}

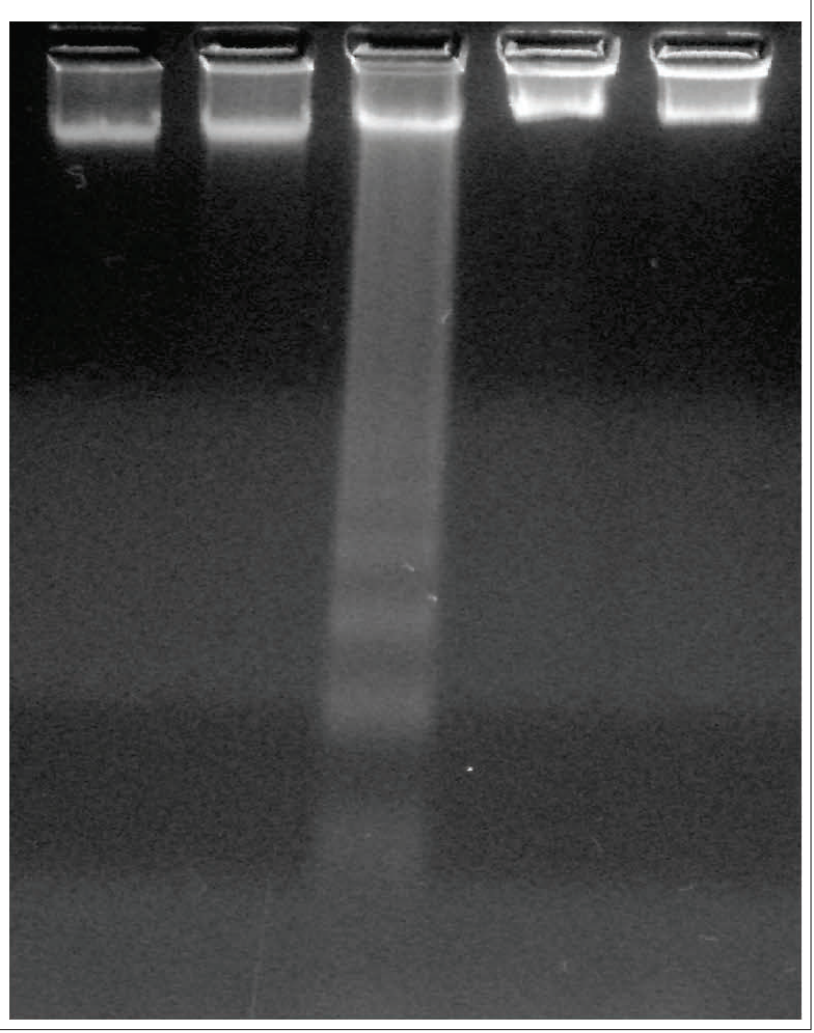

Fig. 5. Coladerm-beta glucan membrane effect on the level of DNA damage in VH10 and B-HNF-1 cells after $24 \mathrm{~h}$ of treatment. Cells growing without the membrane were used as a negative kontrol, $P<0.05$ was considered statistically significant.
Table 3. Mutagenic effect of the coladerm-beta glucan membrane on Salmonella Typhimurium TA98 and

TA100 using the Ames test.

\begin{tabular}{lcc}
\hline & TA98 & TA100 \\
\cline { 2 - 3 } & $\mathrm{M}^{\mathrm{a}}$ & $\mathrm{M}^{\mathrm{a}}$ \\
\hline Without membrane & $17,7 \pm 3,1$ & $142 \pm 6,6$ \\
Membrane & $20 \pm 1,7$ & $146 \pm 31,8$ \\
Positive control & $445 \pm 34,5 * * *$ & $1384 \pm 59 * * *$ \\
\hline
\end{tabular}

\section{DISCUSSION}

In our previous work, the coladerm membrane was used as a matrix consisting of a complex of type I atelocollagen and hyaluronan ${ }^{19}$. The cytotoxicity studies of coladerm membrane confirmed that the membrane is non-toxic with suitable structural and biological properties for different clinical application. Beta-glucans manifests a broad spectrum of biological activities ${ }^{5}$ and they are found in the cell wall of yeasts, fungi and pathogenic bacteria and also produced by a variety of plants.

In this study, beta glucan (pleuran isolated from Pleurotus ostreatus), which has a positive effect on wound healing, was added to the previous composition of the coladerm. The aim was to create a suitable covering for topic applications with increased healing activity.

Coladerm-beta glucan membrane was produced from a polyelectrolyte complex of atelocollagen and hyaluronan and beta-glucan. The structure of newly prepared biomaterial is shown in Fig. 1. The complex membrane has a characteristic bubble-like macrostructure after drying which ensures its high cohesiveness also due to chemical cross-linking by dialdehydic starch derivatives. The chemical cross-linking of the membrane by dialdehydic starch derivatives reduces its biodegradability and provides mechanical firmness, which enables saturation.

However, as biomaterials can pose low, medium or high potential risk to human safety, the biological safety assessment of potential medical biomaterials is the first step before other trials. One of the recommended and appropriate biological assessments consists of in vitro evaluation of biocompatibility, cytotoxicity and genotoxicity/ mutagenicity. Biological testing involves a large number of qualitative and quantitative methods that use different cells growing in vitro ${ }^{27,29,33}$.

Therefore, in this study biocompatibility, cytotoxicity, genotoxicity and antimicrobial activity of newly prepared membrane biomaterial were evaluated. The biocompatibility of the CBGM was studied on the base of cell adhesion and colonization of human fibroblast cultures on the biomaterial surface by light microscopy. The MTT test and LDH level determination in the culture medium removed from the control and cells treated on the membrane were used for viability and cytotoxic evaluations. Flow cytometry and gel electrophoresis were used for analysing the cell cycle and death. Comet assay was used for genotoxic study. 


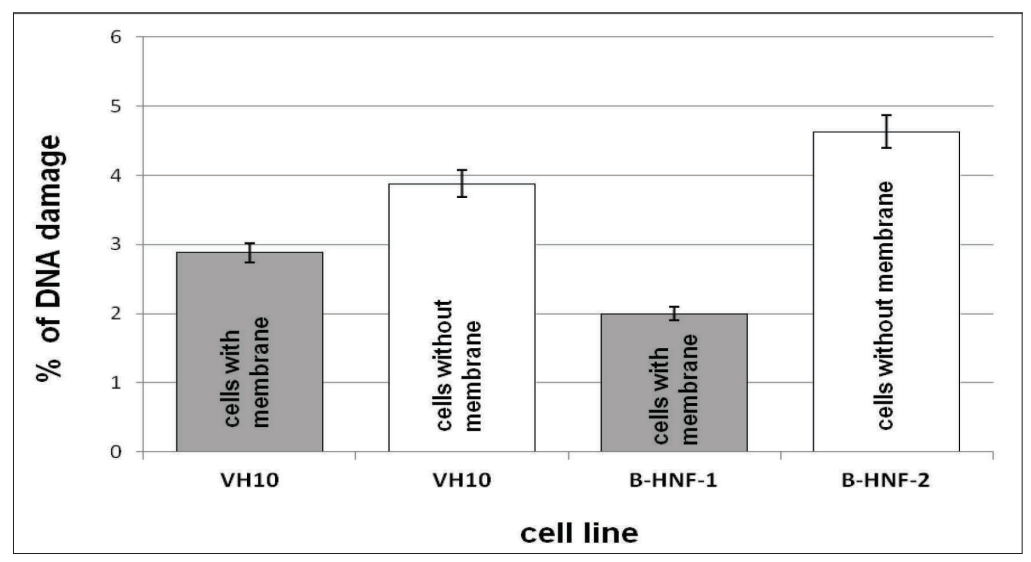

Fig. 6. Fluorescence microscopic analysis of DNA damage of VH10 (A) and B-HNF-1 (B) cells growing $24 \mathrm{~h}$ with/without the coladerm-beta glucan membrane. Magnification 400×.

The biocompatibility studies showed that VH10 cells colonize the coladerm-beta glucan membrane well. A majority of growing cells exhibited typical fibroblast morphology with an elongated and polygonal shape. The ability of human fibroblast cells BHNF-1 to adhere and divide on the membrane surface was also investigated by transmission electron microscope $\mathrm{e}^{24}$. The cells adhered and proliferated on the membrane and their morphology was unchanged compared to control. These results demonstrate that the membrane is biocompatible biomaterial.

The results from cytotoxic studies (MTT and LDH tests) indicated that the CBGM show no cytotoxicity. No significant difference in cell viability or growth was found. LDH test showed that fibroblast cells VH10 and B-HNF-1 did not significantly damage the cytoplasmatic membrane integrity indicating that the tested membrane did not induce necrotic cell death.

The LDH test, flow cytometry and agarose gel electrophoresis demonstrated that CBGM did not induce either necrotic or apoptotic cell death. Membrane-treated cells had similar cell morphology as control cells and had undamaged cytoplasmic membrane integrity (Fig. 2). The VH10 and B-HNF-1 cells did not have fragmented DNA (Fig. 4) and no sub-G $\mathrm{G}_{0}$ cell fraction was detected during the cell analysis (Table 1). Flow cytometry also showed that CBGM slighly affected the cell cycle, the membrane induced decrease in cell number in S and G2/M phase of human fibroblast cells (Table 1).

These results allow us to conclude that the coladermbeta glucan membrane is non-toxic biomaterial.

They are in accordance with Vojtaššák et al. ${ }^{2}$ and Harvanová et al. ${ }^{23}$ whose results from a study of biocompatibility, cell viability and cytotoxicity of the collagen/ hyaluronan membrane (coladerm membrane) showed that the membrane was non-toxic, biocompatible biomaterial suitable for growth of fibroblasts and chondrocytes ${ }^{20}$. Human embryonic fibroblast cells B-HEF-2 proliferated not only around the tested coladerm membrane, but also on its surface and invaded the membrane. This was proven by immunohistochemical examination and scanning electron microscopy analysis ${ }^{2}$.

The results of the toxicity study of the CBGM are also consistent with work of other authors who have shown the non-toxicity of collagen based membranes ${ }^{34-37}$ and human fibroblast ability to attach and proliferate on collagen membranes ${ }^{23,38}$. Non-toxicity and the biomedical applications were also documented for collagen-based scaffolds containing polysaccharides such as chitosan, hyaluronan and other glycosaminoglycans. As well, the collagen spongy matrix containing oxidized regenerated cellulose (ORC) named Promogran ${ }^{\circledR}$ has been designed to treat exuding wounds including diabetic, venous and pressure ulcers ${ }^{39}$. Woo et al. ${ }^{40}$ reported utilization of collagenbased membranes containing beta glucan in regenerative medicine. These authors investigated the possible roles of (1,3)-(1,6)-beta-D-glucan and porous electrospun polylactide-co-glycolide (PLGA) membranes containing betaglucan for skin would healing, especially their effect on activation, proliferation, migration of adult human dermal fibroblast.

Antimicrobial studies of the CBGM on bacteria and filamentous fungi model demonstrated that the coladermbeta glucan membrane induce different antimicrobial effects. The tested membrane exhibited antibacterial activity against G bacteria E. sakazakii, S. marcescens, E. coli and against $\mathrm{G}^{+}$sporogenic bacteria $B$. cereus. No antifungal activity was detected.

Different antimicrobial activity of composites containing hyaluronic acid (HA) or beta-glucan was described also by other authors. Ardizzoni et al. ${ }^{41}$ reported such effects for HA. In particular staphylococci, enterococci, Streptococcus mutans, two Escherichia coli strains, Pseudomonas aeruginosa, Candida glabrata and C. parapsilosis displayed for HA dose dependent growth inhibition. On the other hand, no effects of HA were detected in E. coli ATCC 13768 and C. albicans and S. sanguinis was favored by the highest HA dose. A few human clinical studies on beta glucan have demonstrated a decreased infection incidence in surgical patients and shortened intensive care.

The genotoxicity of the membrane was determined by Ames bacteria gene mutation assay and comet assay. $N$-Methyl- $N$ '-Nitro- $N$-Nitrosoguanidine (MNNG; the stock solution $1 \mathrm{mg} / \mathrm{mL}$ ) was used as positive control in Ames 
tests and dishes without membrane presence were used as a negative control. The CBGM did not induce mutagenicity in the bacterial reverse mutation test in Salmonella Typhimurium strains. Similarly, the comet assay showed that the tested fibroblast cells growing with/without the CBGM showed no statistically significant DNA damage.

Our results from genotoxic studies are consistent with a number of other studies that have investigated the genotoxic/mutagenic activity of biopolymers with a negative effect ${ }^{42-44}$. Moreover, some natural and synthetically prepared biopolymer derivatives promote human health by prevention against DNA damage, mutations and cancer $^{45-51}$.

On the basis of the results it can be concluded that the CBGM has a good biocompatibility, no cytotoxicity/ genotoxicity/mutagenicity and it can be included among potential scaffolds for tissue engineering.

\section{CONCLUSIONS}

The prepared coladerm-beta glucan membrane has a characteristic bubble-like macrostructure after drying which ensures its high cohesiveness also due to chemical cross-linking by dialdehydic starch derivatives. Biocompatibility assessment showed that the membrane did not affect cell morphology or proliferation of human fibroblasts VH10 and B-HNF-1 colonized on the membrane surface. Cytotoxicity studies confirmed that CBGM is a non-toxic biomaterial which does not affect the cell cycle and does not induce either necrotic or apoptotic cell death. The tested membrane exhibited antibacterial activity against $\mathrm{G}^{-}$bacteria $E$. sakazakii, $S$. marcescens, E. coli and against $\mathrm{G}^{+}$sporogenic bacteria $B$. cereus. No antifungal activity was detected. The membrane did not induce mutagenicity in the bacterial reverse mutation test in Salmonella Typhimurium strains. Similarly, the comet assay showed that the tested fibroblast cells growing with/ without the membrane showed no statistically significant DNA damage. The results of this study show that the coladerm-beta glucan membrane could be used as a scaffold for tissue engineering and creating a suitable biocovering for topic applications with increased healing activity.

\section{ACKNOWLEDGEMENT}

Authorship contributions: All authors contributed equally to preparing the manuscript.

Conflict of interest statement: The authors stated that there are no conflicts of interest regarding the publication of this article.

\section{REFERENCES}

1. Mano JF, Silva GA, Azevedo HS, Malafaya PB, Sousa RA, Silva SS Boesel LF, Oliveira JM, Santos TC, Marques AP, Neves NM, Reis RL. Natural origin biodegradable systems in tissue engineering and regenerative medicine: present status and some moving trends. J Roy Soc Int 2007;4:999-1030. doi:10.1098/rsif.2007.0220
2. Vojtaššák J, Danišovič $L$, Kubeš $M$, Bakoš $D$, Jarábek $L$, Uličná $M$, Blaško M. Autologous biograft and mesenchymal stem cells in treatment of the diabetic foot. Neuro Endocrinol Lett 2006;2,134-7.

3. Chen J, Seviour R. Medicinal importance of fungal beta$(1 \rightarrow 3),(1 \rightarrow 6)$-glucans. Mycol Res 2007;111:635-52.

4. Akramiene D, Kondrotas A, Didžiapetriene J, Kevelaitis E. Effects of beta glucans on immune system. Medicina (Kaunas) 2007:43(8):597604.

5. Akramiene D, Aleksandraviciene C, Grazeliene G, Zalinkevicius R, Suziedelis K, Didziapetriene J, Simonsen U, Stankevicius E, Kevelaitis E. Potentiating effect of beta glucans on photodynamic therapy of implanted cancer cells in mice. Tohoku J Exp Med 2010;220:299-306. doi:10.1620/tjem.220.299

6. Bergendiová K, Tibenská E, Majtán J. Pleuran (Beta glucan from Pleurotus ostreatus) supplementation, cellular immune response and respiratory tract infections in artletes. Eur J Appl Phys 2011;111:203340.

7. Rahar S, Swami G, Nagpal N, Nagpal MA, Singh GS. Preparation, characterization and biological properties of beta glucans. J Adv Pharm Technol Res 2011;2(2):94-103. doi:10.4103/2231-4040.82953

8. Kaneko Y, Chihara G, Taguchi T. Activity of lentinan against cancer and AIDS. Int J Immunother 4:1989;203-13.

9. Mantovani MS, Bellini MF, Angeli JPF, Oliveira RJ, Silva AF, Ribeiro LR. Beta glucans in promoting health: prevention against mutation and cancer. Mut Res 2008:658:154-61. doi:10.1016/j.mrrev.2007.07.002

10. Wasser SP. Medicinal mushrooms as a source of antitumor and immunomodulating polysaccharides. Appl Microbiol Biotechnol 2002:60(3):258-74. doi:10.1007/s00253-002-1076-7

11. Ren $L$, Perera $C$, Hemar $Y$. Antitumor activity of mushroom polysaccharides: a review. Food Funct 2012: in press

12. Chen J, Raymond K. Beta-glucans in the treatment of diabetes and associated cardiovascular risks. Vasc Health Risk Manag 2007;4(6):1265-72.

13. Nosálová V, Bobek P, Černá S, Galbavý S, Stvrtina S. Effects of pleuran (beta-glucan isolated from Pleurotus ostreatus) on experimental colitis in rats. Phys Res 2001;50(6):575-81.

14. Majtán J, Kumar P, Koller J, Dragúňová J, Gabriz J. Induction of metalloproteinase 9 secretion from human keratinocytes by pleuran (beta-glucan from Pleurotus ostreatus). Zeit Natur C 2009;64(78):597-600.

15. Rop O, Mlcek J, Juriková T. Beta-glucans in higher fungi and their health effects. Nut Rev 2009;67(11):624-31.

16. Rovenský J, Stančíková M, Švík K, Bauerová K, Jurkovičová J. The effects of ß-glucan isolated from Pleurotus ostreatus on methotrexate treatment in rats with adjuvant arthritis. Rheum Int 2011;31:507-11.

17. Kurashige S, Akuzawa Y, Endo F. Effects of Lentinus edodes, Grifola frondosa and Pleurotus ostreatus administration on cancer outbreak, and activities of macrophages and lymphocytes in mice treated with a carcinogen, N-butyl-N-butanolnitrosoamine. Immun Immunotox 1997;19(2):175-83.

18. Bobek P, Galbavý S. Effect of pleuran (beta-glucan isolated from Pleurotus ostreatus) on the antioxidant status of the organism and on dimethylhydrazine-induced precancerous lesions in rat colon. $\mathrm{Br}$ J Biomed Sci 2001;58(3):164-8.

19. Vizárová K, Bakoš D, Reháková M, Petríková M, Panáková E, Koller J. Modification of lavyered atelocollagen: enzymatic degradation and cytotoxicity evaluation. Biomaterials 1995;16:1217-21.

20. Vojtaššák J, Bakoš D, Danihel L', Krištín J, Böhmer D, Danišovič L', Blaško M. In vitro cytotoxicity testing of coladerm membrane. Cell Tiss Bank 2001:2:225-33.

21. Vojtaššák J, Poruban D, Bakoš D, Danihel L', Böhmer D, Danišovič L, Danihelová A, Blaško M. Mouth cavity base defect treated with biosynthetic graft. Biologia 2006;61:713-8.

22. Poruban $D$, Bakoš $D$, Danišovič $L$, Bohmer $D$, Blaško $M$, Vojtaššak J. In vitro prepared autologous graft from bucal mucosa - clinical application. Case Rep Clin Pr Review 2005;6:62-7.

23. Harvanová $D$, Rosocha J, Bakoš $D$, Švihla R, Vaško G, Horňák $S$ Ledecký V, Gromošová S, Cibur P, Raši R. Collagen/hyaluronan membrane as a scaffold for chondrocytes cultivation. Biologia 2009;64(5):1032-8.

24. Jantová $S$, Bakoš D, Matejov $P$, Danišovič L', Melušová M. 2011: The study of biocompatibility and cytotoxicity of Coladerm-glucan membrane on human cells. Int Toxicol 2008;4(2):A36. 
25. Mossman T. Rapid colorimetric assay for cellular growth and survival application to proliferation and cytotoxicity assays. J Imm Meth 1983;65:55-62.

26. Bergmeier HU. Methoden der enzymatischen Analyse. 1970: 2nd ed. Akademie Verlag, Berlin.

27. Theiszová M, Jantová S, Letašiová S, Palou M, Čipák L. Cytotoxicity of hydroxyapatite, fluorapatite and fluor-hydroxyapatite: a comparative in vitro study. Neoplasma 2008;4:312-6.

28. Singh NP, McCoy MT, Tice RR, Schneider EL. A simple technique for quantification of low levels of DNA damage in individual cells. Exp Cell Res 1988;175:184-91.

29. Slameňová D, Gábelová A, Ruppová K. Cytotoxicity and genotoxicity testing of sodium fluoride on Chinese hamster V79 cells and human EUE cells. Mut Res 1992;16:109-15.

30. Gábelová A, Slameňová D, Ružeková L, Farkašová T, Horváthová E. Measurement of DNA strand breakage and DNA repair induced with hydrogen peroxide using single cell gel electrophoresis, alkaline DNA unwinding and alkaline elution of DNA. Neoplasma 1997;44:380-8.

31. Bodajla M, Stankovský Š, Špirková K, Jantová S, Hudcová D Azolylquinazolines, synthesis and biological activity. Chem Paper 1994;48(6):432-6.

32. Maron DM, Ames BN. Revised methods for Salmonella mutagenicity test, Mut Res 1983;113(3-4):173-215.

33. Esposito A, Mezzogiorno A, Sannino A, De Rosa A, Menditti D, Esposito V, Ambrosio L. Hyaluronic acid based materials for intestine tissue engineering: A morphological and biochemical study of cell-material interaction. J Mat Sci: Mat Med 2006;17:1365-72.

34. Ruozi, B, Parma B, Croce M.A, Tosi G, Bondioli L, Vismara S, Forni F, Vandelli MA. Collagen-based modified membranes for tissue engineering: influence of type and molecular weight of GAGs on cell proliferation. Int J Pharm 2009;378(1-2):108-15.

35. Yang Z, Mo L, Duan H, Li X. Effects of chitosan/collagen substrates on the behavior of rat neural stem cells. Sci China Life Sci 2010;53(2):215-22.

36. Berahim Z, Moharamzadeh K, Rawlinson A, Jowett AK. Biologic interaction of three-dimensional peridontal fibroblast spheroids with collagen-based and synthetic membranes. J Periodont 2011;82(5):790-7.

37. Akturk O, Tezcaner A, Bilgili H, Deveci MS, Gecit MR, Keskin D. Evaluation of serin/collagen membranes as perspective wound dressing biomaterial. J Biosc Bioeng 2011;112(3):279-88.

38. Behring J, Junker R, Walboomers XF, Chessnut B, Jansen JA. Toward quided tissue and bone regeneration: morphology, attachment, proliferation, and migration of cells cultured on collagen barrier membranes. A systematic review. Odontology 2008;96:1-11.

39. Ruszczak Z. Effect of collagen matrices on dermal wound healing. Adv Drug Dil Rev 2003;55:1595-611.
40. Woo YI, Park BJ, Kim HL, Lee MH, Kim J, Yang YI, Kim JK, Tsubak, K. The biological activities of $(1,3)-(1,6)$-beta-d-glucan and porous electrospun PLGA membranes containing beta-glucan in human dermal fibroblasts and adipose tissue-derived stem cells. Biomed Mat 2010;5(4):044109.

41. Ardizzoni A, Neglia RG, Baschier MC, Cermelli C, Caratozzolo M, Righ E, Palmieri B, Blasi E. Influence of hyaluronic acid on bacterial and fungal species, including clinically relevant opportunistic pathogens. J Mat Sci: Mat Med 2011; 22(10):2329-38.

42. Muramatsu K, Nakajima M, Kikuchi M, Shimada S, Sasaki K, Masuda $\mathrm{S}$, Yoshihara Y. In vitro cytocompatibility assessmant of beta-tricalciu phosphate/carboxymethyl-chitin composite. J Biomed Mat Res: Part A 2004;71(4):635-43.

43. Marone PA Lau FC, Gupta RC, Bagchi M, Baghi D. Safety and toxicological evaluation of undenatured type II collagen. Tox Mech Meth 2010;20(4):175-89.

44. Lim CK, Yaacob NS, Ismail Z, Halim AS. In vitro biocompatibility of chitosan porous skin regenerating templates (PSRTs) using primary human skin keratinocytes. Tox In Vitro 2010;24(3):721-7.

45. Lazová M, Lábaj J, Kováciková Z, Slameňová D. Diet containing fungal (1-3)-beta-D-glukan derivative exhibits protective effects against DNA lesions induced in freshly isolated rat cells. Neoplasma 2004;51(6):431-5.

46. Lazarová M, Lábaj J, Eckl P, Kogan G, Slameňová D. Effects of dietary intake of a fungal beta-D-glucan derivative on the level of DNA damage induced in primary rat hepatocytes by various carcinogens. Nut Cancer 2006;56(1):113-22.

47. Miadoková E, Svidová S, Vlčková V, Dúhová V, Prazmáriová E, Tothová K, Nad'ová S, Koganm G, Rauko P. The role of natural biopolymers in genotoxicity of mutagens/carcinogens elimination. Biomed Pap Med Fac Univ Palacky Olomouc Czech Repub 2005;149(2):493-6.

48. Yoon HJ, Park HS, Bom HS, Roh YB, Kim JS, Kim YH. Chitosan oligosaccharide inhibits $203 \mathrm{HgCl}_{2}$-induced genotoxicity in mice: micronuclei occurrence and chromosomal aberration. Arch Pharm Res 2005;28(9):1079-85.

49. Slameňová D, Lábaj J, Križková L, Kogan G, Sandula J, Bresgen N Eck, P. Protective effects of fungal (1-3)-beta-D-glucan derivatives against oxidative DNA lesions in V79 hamster lung cells. Can Lett 2003;198(2):153-60.

50. Horváthová E, Eckl PM, Bresgen N, Slameňová D. Evaluation of genotoxic and cytotoxic effects of $\mathrm{H} 2 \mathrm{O} 2$ on freshly isolated rat hepatocytes; protective effects of carboxymethyl chitin-glucan. Neuro-End Lett 2008;29(5):644-8.

51. Magnani M, Astro-Gomez RJH, Mori MP, Kuasne H, Gregório EP, Libos F (Jr.), Cólus IMS. Protective effect of carboxymethyl-glucan (CM-G) against DNA damage in patiens with advanced prostate cancer. Gen Mol Biol 2011;34(1):131-5. 